\title{
Tuning of Intercalation and Electron Transfer Processes between DNA and Acridinium Derivatives through Steric Effects
}

\author{
Joshy Joseph,$^{\dagger}$ Elizabeth Kuruvilla, ${ }^{\dagger}$ Asha T. Achuthan, ${ }^{\dagger}$ Danaboyina Ramaiah ${ }^{* \dagger}$ and \\ Gary B. Schuster * \\ ${ }^{\dagger}$ Photosciences and Photonics Division, Regional Research Laboratory (CSIR) \\ Trivandrum 695019, INDIA \\ ${ }^{\star}$ School of Chemistry and Biochemistry, Georgia Institute of Technology, \\ Atlanta, Georgia 30332-0400, USA
}

\section{Supporting Information}

Figures S1-S4, showing the absorption and fluorescence emission spectra of the acridinium derivatives $\mathbf{1}$ and 3-5 in the presence and absence of calf thymus DNA and Figure S5 showing the absorption spectra of 2 in the presence and absence of poly(dA).poly(dT) and poly(dG).poly(dC). 




Figure S1. Change in absorption spectra of $1(17.5 \mu \mathrm{M})$ in phosphate buffer (10 $\mathrm{mM}, \mathrm{pH}$ 7.4) with increasing concentration of CT DNA. [DNA] (a) 0 and (f) 0.78 $\mathrm{mM}$. Inset shows the change in fluorescence spectra of $\mathbf{1}$ under similar conditions. [DNA] (a) 0 and (h) $1.22 \mathrm{mM}$. Excitation wavelength, $363 \mathrm{~nm}$. 


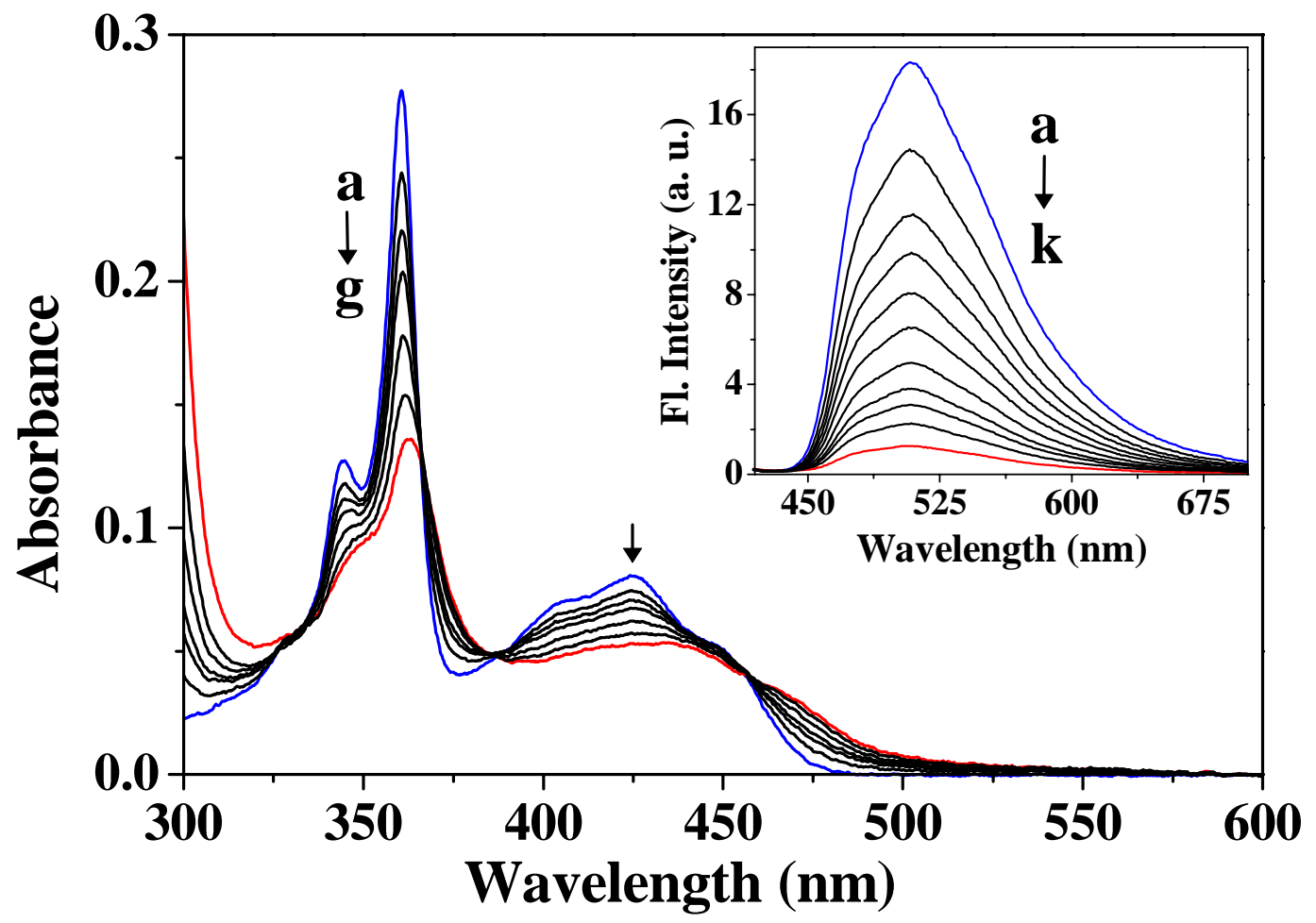

Figure S2. Change in absorption spectra of $\mathbf{3}(15 \mu \mathrm{M})$ in phosphate buffer (10 $\mathrm{mM}, \mathrm{pH}$ 7.4) with increasing concentration of CT DNA. [DNA] (a) 0 and (g) 1 $\mathrm{mM}$. Inset shows the change in fluorescence spectra of $\mathbf{3}$ under similar conditions. [DNA] (a) 0 and (k) $1.2 \mathrm{mM}$. Excitation wavelength, $366 \mathrm{~nm}$. 


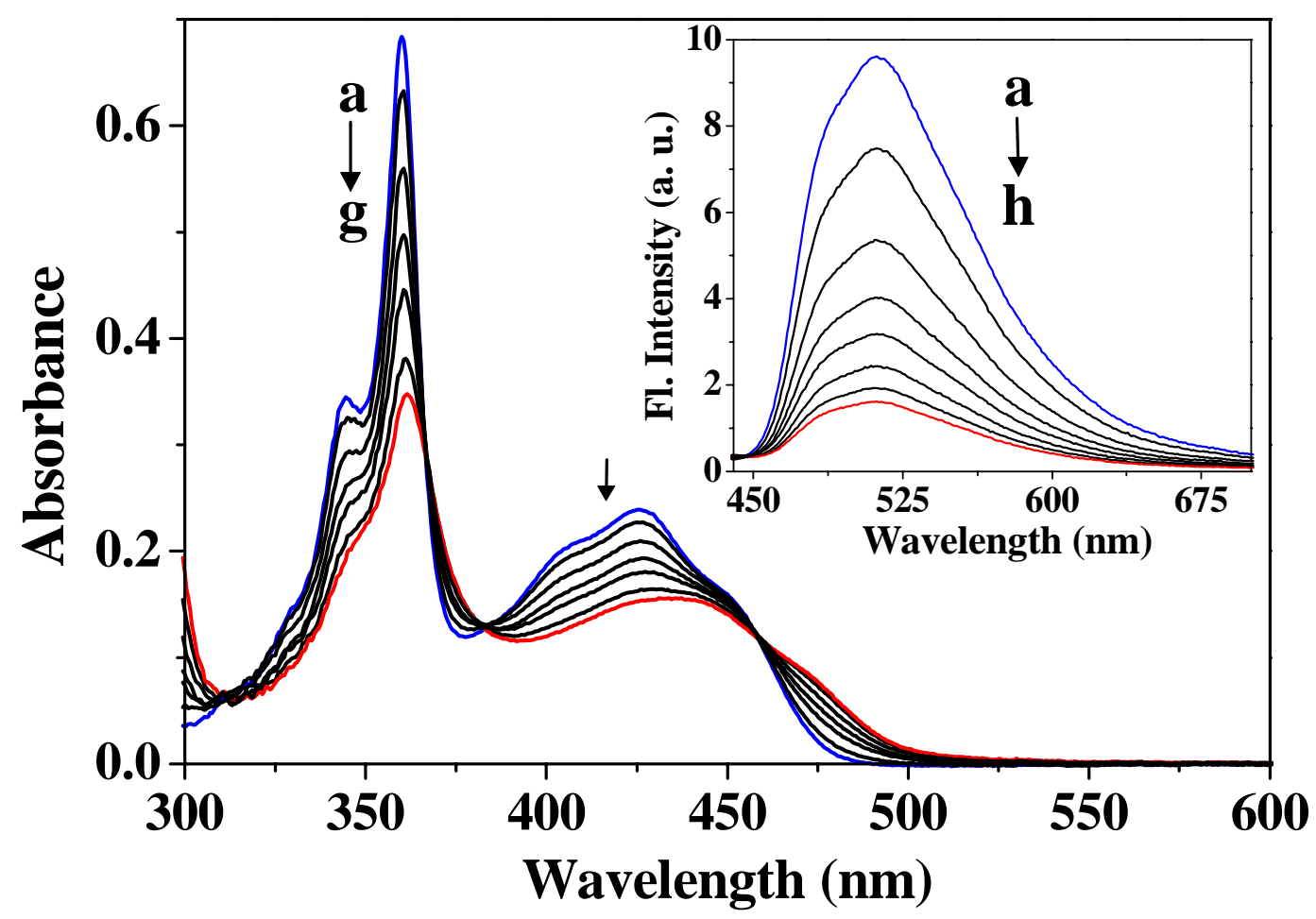

Figure S3. Change in absorption spectra of $4(36 \mu \mathrm{M})$ in phosphate buffer (10 $\mathrm{mM}, \mathrm{pH}$ 7.4) with increasing concentration of CT DNA. [DNA] (a) 0 and (g) 0.56 $\mathrm{mM}$. Inset shows the change in fluorescence spectra of $\mathbf{4}$ under similar conditions. [DNA] (a) 0 and (h) $0.56 \mathrm{mM}$. Excitation wavelength, $366 \mathrm{~nm}$. 


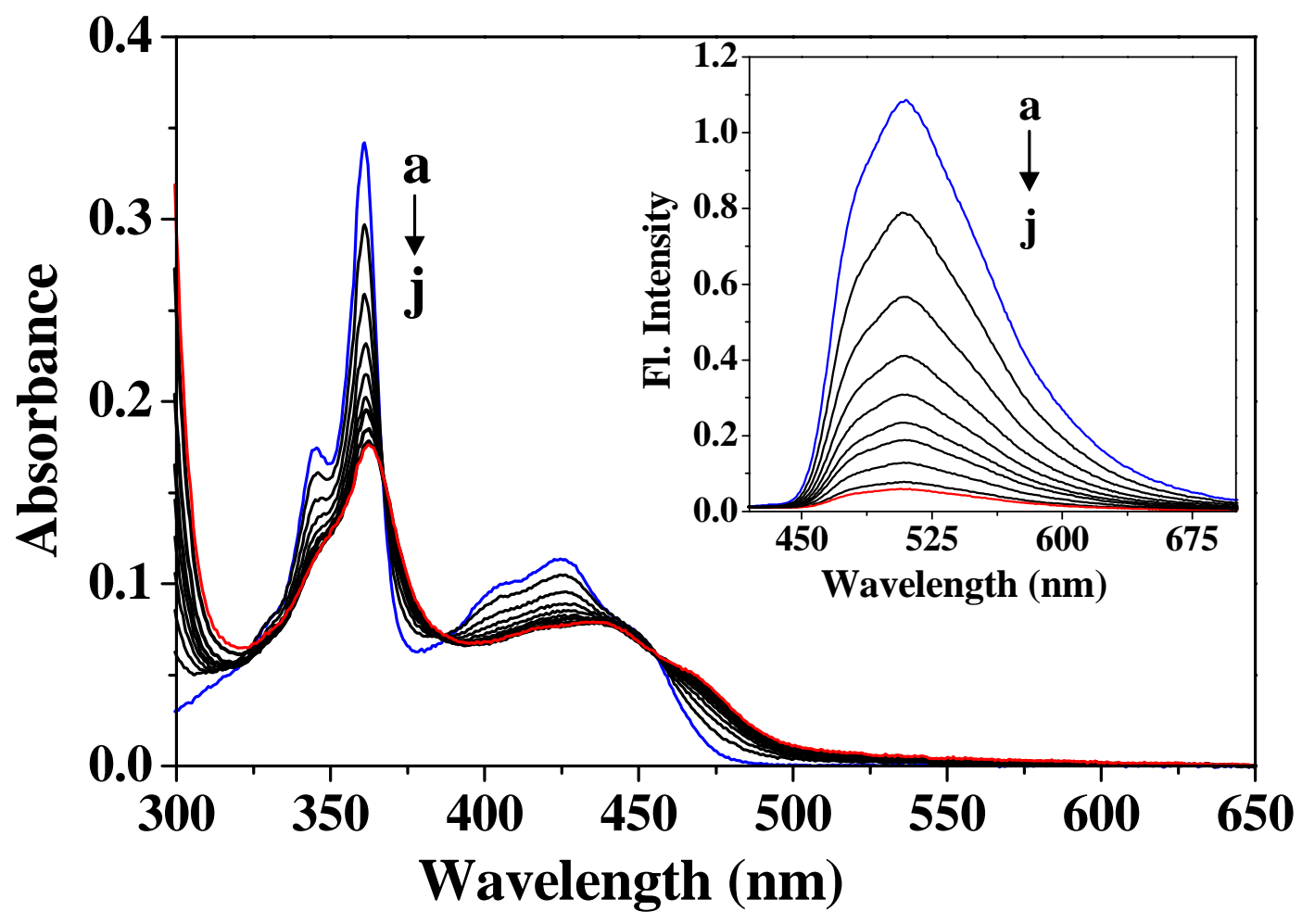

Figure S4. Change in absorption spectra of $5(22 \mu \mathrm{M})$ in phosphate buffer (10 $\mathrm{mM}, \mathrm{pH}$ 7.4) with increasing concentration of CT DNA. [DNA] (a) 0 and (j) 1 $\mathrm{mM}$. Inset shows the change in fluorescence spectra of $\mathbf{5}$ under similar conditions. [DNA] (a) 0 and (j) $1 \mathrm{mM}$. Excitation wavelength, $366 \mathrm{~nm}$. 


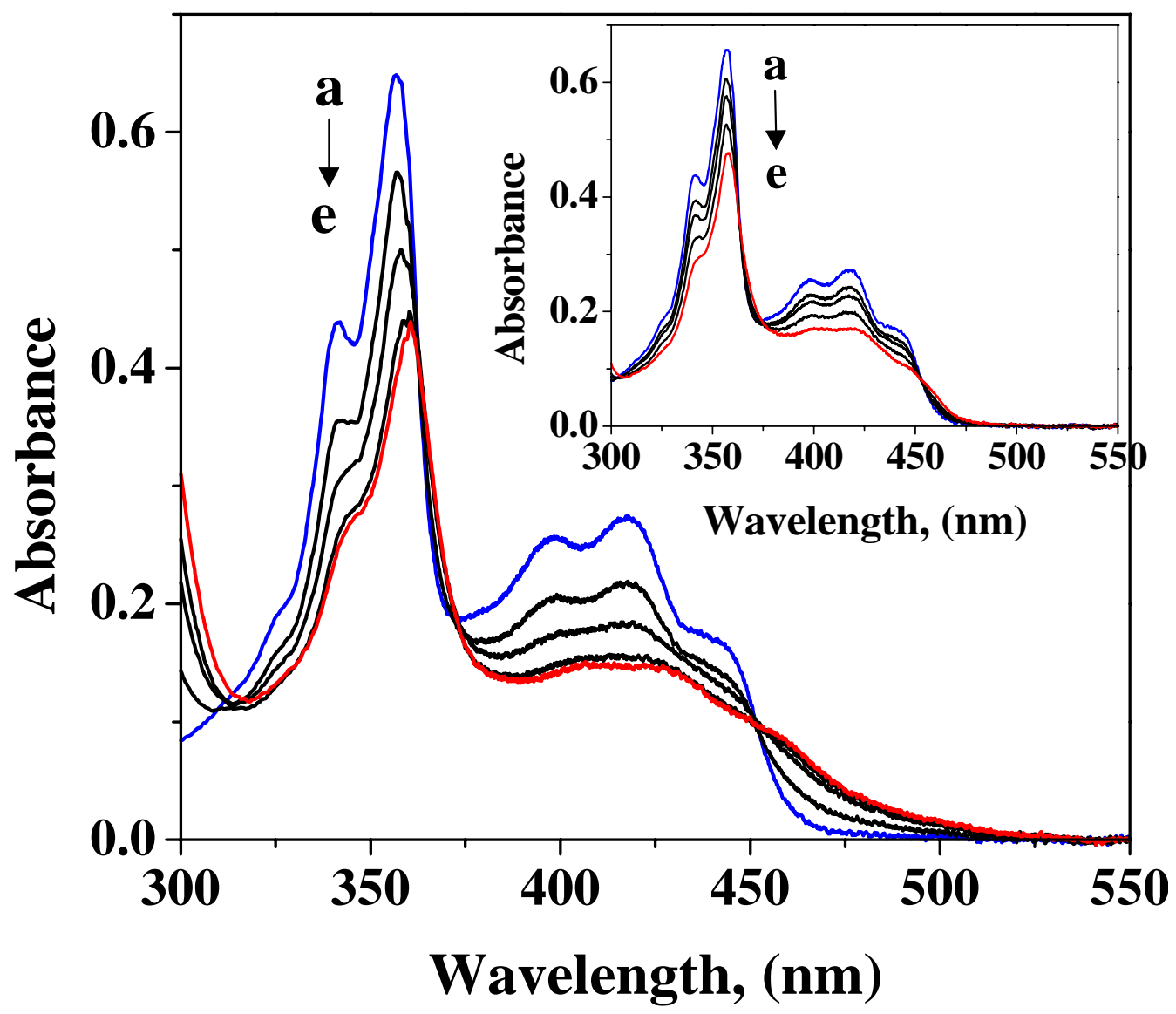

Figure S5. Change in absorption spectra of $2(32 \mu \mathrm{M})$ in phosphate buffer (10 $\mathrm{mM}$, $\mathrm{pH}$ 7.4) with increasing concentration of poly(dG).poly $(\mathrm{dC})$. [poly(dG).poly(dC)] (a) 0 and (e) $0.30 \mathrm{mM}$. Inset shows the change in absorption spectra of 2 with increasing concentration of poly(dA).poly(dT) under similar conditions.[poly(dA).poly(dT)] (a) 0 and (e) $0.33 \mathrm{mM}$. 